\title{
STUDENTS' MOTIVATION IN NATURAL SCIENCE CLASSES
}

\author{
Marija Sablić ${ }^{1}$, Ana Mirosavljević ${ }^{2}$, Irena Labak \\ 1 Josip Juraj Strossmayer University in Osijek, Croatia \\ 2 University of Slavonski Brod, Croatia
}

\begin{abstract}
The paper discusses motivation as an integral part of the learning process. It presents the interdependence of motivation, emotions, self-regulated learning, cognition, metacognition, critical and creative thinking, learning strategies, and teacher in the process of learning within the natural science field. We describe the characteristics of internal and external motivation significant for improving engagement in the natural science learning activities that leads to better learning achievements. A review of relevant research on the specifics of teaching natural science subjects is discussed in the context of motivation, i. e. the paper discusses the factors that motivate students for studying and succeeding in natural science subjects. Students' interest in natural science subjects depends largely on the teacher, but also on a positive, supportive, and engaging learning environment. Due to teachers' importance and numerous interrelationships in the entire learning process, they have a responsibility to motivate students, but also to motivate themselves for professional development in which they will improve their knowledge of factors that motivate students. The paper analyses which factors motivate students for optimal achievements in classes, for effective and active participation in the teaching process of natural science subjects, but also for developing a positive attitude towards the natural sciences.
\end{abstract}

Keywords: learning activities, natural science subjects, student motivation, success, teacher.

\section{Introduction}

Motivation is an internal force that activates and guides our thoughts, feelings, and actions (Mubeen, Reid, 2014) and it is indispensable in the discussion on contributing to the quality of learning, better achievements, and improvement of the educational process in general and in science education. It is becoming an increasing challenge for teachers to motivate students to learn. For teachers to be successful in this endeavor, they themselves must be motivated to motivate students, and targeted self-evaluation of their teaching helps in identifying needs and opportunities to motivate students. 
Motivation is an essential part of learning. Given that in natural science subjects, there is a decline in students' interest in the subject, lack of deep understanding, inability to use the acquired knowledge, and overall apathy for learning (Fúz, 2018), this paper is focused on motivation in studying and teaching natural science subjects. This paper intends to show the interdependence of motivation, emotions, self-regulated learning, cognition, metacognition, critical and creative thinking, learning strategies, and external factors in the process of studying natural science subjects. The aim of studying in natural science subjects is not simply to learn the contents set by the curricular outcomes but also to educate students in natural science and sciences in general. The key for succeeding is stimulating and fostering intrinsic motivation for learning natural science, i. e., to increase students' interest in learning natural science and present it as valuable, meaningful, and useful to them.

\section{Internal and external motivation}

Taylor (2012) attributes intrinsic motivation to students who show real interest in the learning process and seek to increase their knowledge of the content, while extrinsic motivation is attributed to students who show interest in participating in a task due to an external cause, such as flaunting their abilities, competing with others, or certain external gain such as achieving good grades, recognition or reward. Even though intrinsic and extrinsic motivation are often analyzed as mutually exclusive in such a way that an individual with high internal motivation shows a low level of external motivation (Hayenga, Corpus, 2010), the reality is somewhat different, i. e. majority of students are motivated by both internal and external factors, which mainly depends on the task (Clinkenbeard, 2012).

Enabling students to make choices (related to teaching materials, tasks they do, peers they work with, etc.) could enhance their engagement and motivation, allow them to make the most of their strengths, and meet individual learning needs (Parker et al., 2017). Froiland, Worrell (2016) equate intrinsic motivation with enjoyment in the learning process and associate it with a variety of elements including long-term achievements, conceptual understanding, giftedness, less anxiety during homework, persistence in educational tasks, and lower dropout rates. A lack of student engagement in a particular activity does not indicate the lack of motivation in students, rather that they are motivated for something else at that point (Perks, Middleton, 2014). 


\section{Methodology}

The paper provides literature review about students' motivation in natural science classes.

The goal was to study the different ways of students' motivation in natural science classes and it's effect their learning outcomes. In addition, we analyzed the role of teachers' contribution in students' motivation.

The following research questions are put forward:

1. What motivates students in natural science classes?

2. How teachers effect on students interest and motivation in natural science classes?

In order to answer the research questions, we searched the following scientific databases: EBSCOhost, ERIC, Google Scholar, J-Store, SAGE and ScienceDirect. Initial key words were identified from the researchers' knowledge of the field. These included student motivation, natural science subjects, teacher, intrinsic motivation, extrinsic motivation, learning environments. The free Zotero application (https://www.zotero.org/) was used to store the chosen list of references. All three authors independently chose the relevant list of references. Eligibility of review was assessed using the following inclusion criteria for the studies included in their samples: a) Publication year covered the period from 2007 to 2018; b) Research methodologies: quantitative, qualitative, mixed-method and review articles; c) Studies that were school-based.

\section{Discussion}

In this section, we critically discuss the literature based on students' motivation in natural science classes. The review provides a concise summary of the most important factors influencing students enjoyment of natural science classes and relevant description of the students' motivation topic as well as its overall perspective, argument, or purpose.

Motivation is a crucial factor in any effective learning. It is difficult to generate the motivation necessary to complete the task and it is almost impossible to perform the task well without the positive attitude towards the learning task (Mubeen, Reid, 2014). It is highly important that the rapport of the teacher towards a student is warm, respectful, and compassionate. The results of the research (Pitzer, Skinner, 2017) confirm the importance of teachers in the dynamics of teaching and indicate that the increase in the level of motivation in students is related to the amount of teacher support that students receive during the school year. Research shows that student motivation is strongly predicted by self-confidence and moderately predicted by the teacher's emotional support that 
is positively associated with student self-assessment and motivational responses (Skaalvik et al., 2015).

Grades are one of the biggest obstacles to motivation. For students who make less progress in learning, grades can significantly stifle self-confidence, self-esteem, and reduce motivation for future learning (Mubeen, Reid, 2014). In other words, students who cannot improve effective learning skills are not able to motivate themselves to learn, plan their learning processes and evaluate these processes in case of improving grades (Demir et al., 2012). To reduce the negative effect of grading on motivation, it is very important to approach formative evaluation and self-evaluation as a fundamental concept of self-regulated learning that improves motivation and learning autonomy (Brown, Harris, 2013).

Teacher knowledge and motivation are two key characteristics of successful education (Mahler et al., 2018). This is also indicated by the results of the research by the mentioned authors, which suggest that teacher training should not only focus on acquiring knowledge, but also on improving motivational orientation. Students feel most motivated by teachers who demonstrate new skills, provide support and encouragement, and help them learn from their mistakes (Cushman, 2014). The teacher facilitates teaching by motivating students to explore new ideas, pose interesting questions (Beuermann et al., 2013), and to apply their knowledge in novel situations. Continuous teacher training is necessary so that the teacher is able to innovate in classes, stimulate students' motivation and interest by applying theory and practice, so that students better assimilate the content, relating it to their everyday lives (Soares et al., 2016).

Planning motivational procedures is an indispensable part of any lesson planning. Horvat (2018) emphasizes that motivation, as a complex and long-lasting process, should not be observed only during the initial part of the lesson which aims to raise students' interest in a particular unit, but the approach needs to be broader and start in the curriculum planning. This is because motivation cannot fulfill its purpose in an individual lesson, but on a more general level in the context of the overall relationship of students with natural science subjects. Still, it is very important to begin each lesson with a well-designed and implemented motivation that affects student activity throughout the lesson, but also in subsequent learning.

A series of activities need to be carried out in the classroom with the aim of strengthening motivation and learning life skills such as creative problem solving, critical and divergent thinking, logical connection, and quite importantly, encouraging students' independence in learning and practical tasks. It is of great importance to raise awareness in natural science teachers that experiment arouses students' interest at different levels of learning because experiment increases learning ability by including 
students in topics covered during the educational process (Soares et al., 2016). According to a report to the European Commission (Rocard et al., 2007), research-based learning holds great benefits and has been shown to increase student interest and educational accomplishments at primary and secondary levels, while having a positive effect on teacher motivation. Varieties of research-based strategies have proven successful in increasing students' motivation, especially research related to real-world problems. The incentive to observe nature and one's environment as the cornerstone and beginning of the research and learning process also enhances learning motivation (Madden, 2011).

O'Shea (2017) argues that using video materials in the teaching process can be a great way for teachers to encourage enthusiasm and motivate students to learn. Furthermore, Alsied, Pathan (2013) believe that computer technology increases the level of motivation in students and makes the learning process more enjoyable. In this regard, Letina (2015) in numerous studies finds that the implementation of computer technology in natural science teaching increases students' interest and motivation for science and their participation in teaching activities, while also enabling active, constructive, contextual, self-regulated, and collaborative learning.

Learning outside of the classroom could be a very effective factor in the enhancement of natural science education if thoroughly and carefully planned and carried out by actively involving students in the learning process. Teaching in different locations, due to changes in the everyday school environment, in both buildings and natural environments, i. e. places suitable for learning methods and active participation of students (e. g. museums, laboratories, zoos, botanical gardens, national parks, forests, science centers...) lead to an increase in students' motivation to learn (Fúz, 2018). Creating a student-centered environment that enables research instead of traditional teaching, argumentative discussion, analysis, etc., creates an environment where students become more responsible for their learning, and thus are more motivated and engaged and can act at a higher cognitive level (Kazempour, Amirshokoohi, 2014).

\section{Conclusion}

The predictors of any successful learning are motivation and positive attitude towards learning. Studying natural science subjects is important not only because of the acquisition of specific competencies but also because the foundation of studying natural science subjects is based on the use of scientific methodology, i. e., studying is also aimed at the science literacy of students. Seeing that the learning competence supports the development of other competencies, it is necessary to observe motivation 
as a part of natural science competence and know which factors influence its development, i. e., to deeply understand the interrelationships.

Teachers face a great challenge because they need to focus their teaching on the development of competencies, and at the same time motivate students to learn in an environment that encourages such development. An additional aggravating factor is a fact that motivation is complex and interdependent with numerous other factors. Given that motivation varies depending on the task and context, motivating students in natural science classes often requires a combination of perceptual components such as setting clear goals, providing support to students, adequate feedback, learning environment and use of practical activities.

A stimulating and quality learning environment that enables student choice and autonomy whenever possible and the use of tasks of higher cognitive levels are some of the indicators of increased students' motivation and engagement in the teaching of the natural science subjects. Students are more motivated by teachers who show empathy. While internal motivation is characterized by the active participation of students, without having to be rewarded, external is characterized by the focus on grades, awards, and recognitions. Enabling students to participate in research activities and argumentative discussions, encouraging critical thinking, problem-solving, logical reasoning, connecting content with everyday life, and developing divergent thinking can improve students' natural science skills and improve their attitudes about the natural sciences.

Finally, student motivation is not constant and unchanging and can be positively or negatively influenced by teachers, the class environment, and parents (family). However, the students' motivation and engagement depend on the personal experiences of the individual and the understanding of their abilities, which is why students must have a clear vision of personal goals and learning goals, which is the basis of lifelong learning.

\section{Acknowledgements}

This paper is subsidized by the Croatian Science Foundation in project IP-2018-01-8363.

\section{References}

Alsied, S. M., \& Pathan, M. M. (2013). The Use of Computer Technology in EFL Classroom: Advantages and Implications. IJ-ELTS: International Journal of English Language \& Translation Studies, 1(1), 61-71.

Beuermann, D. W., Naslund-Hadley, E., Ruprah, I. J., \& Thompson, J. (2013). The Pedagogy of Science and Environment: Experimental Evidence from Peru. The Journal of Development Studies, 49(5), 719-736. 
Brown, G. T. L., \& Harris, L. R. (2013). Student self-assessment. In McMillan, J. H. (Ed.), The SAGE handbook of research on classroom assessment (pp. 367-393). Thousand Oaks, CA: Sage.

Clinkenbeard, P. R. (2012). Motivation and gifted students: implications of theory and research. Psychology in the Schools, 49(7), 622-630. https://doi.org/10.1002/pits.21628

Cushman, K. (2014). Conditions for motivated learning. Phi Delta Kappan, 95(8), 18-22.

Demir, S., Kilinc, M., \& Dogan, A. (2012). The Effect of Curriculum for Developing Efficient Studying Skills on Academic Achievements and Studying Skills of Learners. International Electronic Journal of Elementary Education, 4(3), 427-440.

Froiland, J. M., \& Worrell, F. C. (2016). Intrinsic motivation, learning goals, engagement, and achievement in a diverse high school. Psychology in the Schools, 53(3), 321-336.

Fúz, N. (2018). Out-of-School Learning in Hungarian Primary Education: Practice and Barriers. Journal of Experiential Education, 41(3), 277-294. https://doi.org/10.1177/ 1053825918758342

Hayenga, A. O., \& Corpus, J. H. (2010). Profiles of intrinsic and extrinsic motivations: A person-centered approach to motivation and achievement in middle school. Motivation and Emotion, 34(4), 371-383. https://doi.org/10.1007/s11031-010-9181-x

Horvat, Z. (2018). Motivacija u suvremenoj nastavi matematike [Motivation in modern mathematics teaching]. Poučak: časopis za metodiku i nastavu matematike, 19(73), 21-28.

Kazempour, M., \& Amirshokoohi, A. (2014). Transitioning to inquiry-based teaching: Exploring science teachers' professional development experiences. International Journal of Environmental and Science Education, 9(3), 285-309. https://doi.org/10.12973/ ijese.2014.216a

Letina, A. (2015). Računalom podržana nastava prirode i društva [Computer-aided teaching of science and society]. Napredak, 156(3), 297-317.

Madden, K. R. (2011). The use of inquiry-based instruction to increase motivation and academic success in a high school biology classroom. Downloaded from https://scholarworks. montana.edu/xmlui/bitstream/handle/1/1773/MaddenK0811.pdf;sequence $=1$

Mahler, D., Großschedl, J., \& Harms, U. (2018). Does motivation matter? - The relationship between teachers' self-efficacy and enthusiasm and students' performance. PLOS ONE, 13(11): e0207252. https://doi.org/10.1371/journal. pone.0207252

Mubeen, S., \& Reid, N. (2014). The Measurement of Motivation with Science Students. European Journal of Educational Research, 3(3), 129-144.

O'Shea, M. (2017). Engage Students' Creativity Through Animated Whiteboard Video Project. The Education Digest, 82(7), 61-64.

Parker, F., Novak, J., \& Bartell, T. (2017). To engage students, give them meaningful choices in the classroom. Phi Delta Kappan, 99(2), 37-41. https://doi.org/10.1177/ 0031721717734188

Perks, K., \& Middleton, M. (2014). Navigating the Classroom Current. Educational Leadership, 72(1), 48-52.

Pitzer, J., \& Skinner, E. (2017). Predictors of changes in students' motivational resilience over the school year: The roles of teacher support, self-appraisals, and emotional reactivity. International Journal of Behavioral Development, 41(1), 15-29. https://doi.org/ $10.1177 / 0165025416642051$ 
Rocard, M., Cesrmley, P., Jorde, D., Lenzen, D., Walberg-Herniksson, H., \& Hemmo, V. (2007). Science education NOW: A Renewed Pedagogy for the Future of Europe. Brussels, Belgium: Office for Official Publications of the European Communities. Downloaded from https://ec.europa.eu/research/science-society/document_library/pdf_06/report-rocardon-science-education_en.pdf

Skaalvik, E. M., Federici, R. A., \& Klassen, R. M. (2015). Mathematics achievement and self-efficacy: Relations with motivation for mathematics. International Journal of Educational Research, 72, 129-136. https://doi.org/10.1016/j.ijer.2015.06.008

Soares, B. C., Castelhano de Campos, M. E., Thomaz, J. R., Da Cruz Pereira, G., \& Roehrs, R. (2016). The Importance of Experimentation in The Teaching of Sciences to Elementary School. Revista Monografias Ambientais - REMOA, 15(2), 1-17.

Taylor, R. T. (2012). Review of the Motivated Strategies for Learning Questionnaire (MSLQ) Using Reliability Generalization Techniques to Assess Scale Reliability. [Doctoral dissertation, Auburn University]. Auburn University, Alabama.https://etd.auburn. edu/bitstream/handle/10415/3114/Dissertation\%20-\%20TaylorRobin\%202012. pdf? sequence $=2$ \&isAllowed $=\mathrm{y}$

Zotero, Personal research assistant. Accessed 20 August 2020. https://www.zotero.org/ 